\title{
Indonesian Nationalism Insight in the Three Pillars of Higher Education: Reflection at IAIN Pekalongan
}

\author{
Ade Dedi Rohayana \\ IAIN Pekalongan, Pekalongan, Indonesia \\ adededirohayana@iainpekalongan.ac.id \\ Muhammad Jauhari Sofi \\ IAIN Pekalongan, Pekalongan, Indonesia \\ muhammad.jauhari.sofi@iainpekalongan.ac.id
}

\begin{abstract}
This paper aims to portray the role of Higher Education in mainstreaming Indonesian nationalism insight amid the dynamic issue of nationalism in society. It specifically focuses on the extent to which the insight is implemented in the Three Pillars of Higher Education or Tridharma Perguruan Tinggi at IAIN Pekalongan. The study used a descriptive-qualitative approach with data sourced from Renstra, academic instructional guideline, research and community service in 2017 and 2018, period that marks early years of IAIN Pekalongan after its conversion from STAIN. From data analysis, this reflective study argues that, first; the implementation of Indonesian nationalism insight in teaching has been effective only at the policy level. Second, its implementation in research is still limited, i.e. 11 of 134 studies (8.2\%). Third, its implementation in community service has not been accommodated explicitly because the existing programs revolve around community empowerment in specific social and religious areas. The study also presents challenges analysis in the end of discussion.
\end{abstract}

Keywords: IAIN Pekalongan; Indonesian nationalism insight; tridharma 


\begin{abstract}
Abstrak
Makalah ini bermaksud memotret peran Perguruan Tinggi dalam penguatan wawasan keindonesiaan di tengah dinamika kebangsaan yang terus berkembang di masyarakat. Secara khusus, ia ingin mengungkap sejauhmana wawasan keindonesiaan diimplementasikan dalam Tridharma Perguruan Tinggi di IAIN Pekalongan. Kajian ini menggunakan pendekatan deskriptif-kualitatif dengan data yang bersumber dari Renstra (rencana strategis), pedoman pembelajaran akademik, penelitian dan pengabdian kepada masyarakat di tahun 2017 dan 2018, yaitu periode yang menandai tahun-tahun awal IAIN Pekalongan pasca konversi. Dari hasil analisa data, kajian reflektif ini menyimpulkan bahwa, pertama, implementasi wawasan keindonesiaan dalam pengajaran baru berjalan efektif di level kebijakan. Kedua, implementasinya dalam aspek penelitian terhitung masih sedikit, yakni hanya 11 dari 134 penelitian $(8,2 \%)$. Ketiga, implementasinya dalam aspek pengabdian kepada masyarakat belum secara eksplisit terakomodir karena program-program pengabdian yang ada masih berkisar pada pemberdayaan masyarakat dalam bidang-bidang sosial dan keagamaan khusus. Kajian ini juga menghadirkan analisis tantangan di akhir pembahasan.
\end{abstract}

Kata Kunci: IAIN Pekalongan; wawasan keIndonesiaan; tridharma

\title{
A. Introduction
}

The multidimensional crisis in Indonesia is currently as a concern of many parties, including higher education. Issues of sectarianism (Kayane, 2020: 78-96) and religious fanaticism (Mietzner and Muhtadi, 2018: 479-97) in the last two decades have led to horizontal conflicts. The inability to properly respond to globalization (Giddens, 1990: 64) and the misuse of information and communication technology have affected gradual decline in morality (Apriani, 2017: 185-203). The willingness to replace the state ideology by certain groups (Zulkarnain and Purnama, 2016: 31-9) and the political aspiration of some regions for independence are the other manifestation of the crisis. Many schools in Indonesia have also become a target for radicalism (Maulana, 2017: 395-401; Mutohar, 2018; News Desk, 2019). All these phenomena fundamentally show that Indonesian people are encountering a crisis of nationalism, a sense of love and belonging to one nation.

In higher education level, the situation is equally alarming. A report from the State Intelligence Agency or Badan Intelijen Negara (BIN), for example, mentioned that several well-known state universities in Indonesia have been exposed to radicalism. The agency also revealed that from the results of data development in 2018, 39 percent of college students in 15 
provinces showed their interest in radical religious understanding (Halim, 2018). Meanwhile, Alvara Research Center noted that $17.8 \%$ of college students supported the establishment of khilafah ideology carried out by HTI or Hizb Tahrir Indonesia (Alvara Research Center, 2018). The surprising fact of this religion-based exclusivism in higher education then causes concern for the plurality of Indonesian people who have been living in harmony for a long time. Such a concern over exclusivism is normal for it tends to go against the spirit of nationalism.

The issue of nationalism in the country has received considerable attention from the world of education. Masamah and Huda, for instance, maintain that nationalism could be mainstreamed through multicultural education in order to build awareness of students for addressing the diversity that exists in Indonesia (2016: 68-81). It can also be fostered through the revitalization of cultural values. According to the historical records, each ethnic group in the country has its own local wisdom, e.g. Bataknese famous with openness, Javanese with subtlety, Madura with high self-esteem, Chinese with tenacity and so forth. Each of them also has a noble tradition in caring for the environment and the nature. Such local values having been inherent from generation to generation can help create a dignified, prosperous and peaceful society in the Indonesia (Marwanti, 2016: 55-63). Other researchers suggest the important role of extracurricular activities in strengthening nationalism in formal schools, such as Pramuka (Surono, 2017: 23-30; Taubah and Chasanah, 2018: 337-54)and Paskibra (Fibrianto and Bakhri, 2018: 75-93; Haryati, 2018: 163-79).

Recent developments in the above-mentioned issue have also heightened the need for attention from higher education in particular. In this sense, higher education has no choice but to participate in mainstreaming Indonesian nationalism insight for both civitas academica and local community in general to arouse their love for the homeland. The said insight for them is a necessity in order to be able to live a good life with mutual understanding in the diverse society of the country. However, such insight doesn't grow by itself; instead, it must be instilled through education. This educational effort can be implemented in the three pillars of higher education or Tridharma Perguruan Tinggi through creativity and innovation in the academic atmosphere of teaching, research and community service. In this way, both civitas academica and local community are expected to obtain better understanding of the national identity to respond to the dynamic issue of nationalism in society.

Several studies have been made to portray the discourse of Indonesian nationalism insight in higher education. First of all, Syahrir observed the Islamic view of Indonesian nationalism insight and the compatibility between Islamic education and the nationalism 
Ade Dedi Rohayana dan Muhammad Jauhari Sofi

insight (Syahrir, 2018: 121-140). Setiawan stated that a curriculum specifically oriented towards Indonesian National Qualification Framework or Kerangka Kualifikasi Nasional Indonesia (KKNI) and nationalism insight is needed in order to respond to the pace of globalization. Here, the curriculum is meant to prepare graduates to have respect for diversity, uphold human dignity, have social care and revive the sense of nationalism (Setiawan, 2016: 349-354). Meanwhile, his other study conducted at Universitas Negeri Medan found that students' understanding, attitude and character dealing with nationalism in general are at a moderate level. A random sampling of $10 \%$ out of 1200 students (i.e. 120 students) was carried out to obtain the research data (Setiawan, 2017: 24-33).

Next, a study by Santoso and Rumambo emphasized the important role of Higher Education in preparing students to have strong Indonesian nationalism insight through character education. In this case, the students need to be provided with civic knowledge, civic skills and civic disposition (Santoso and Rumambo, 2017: 509-20). Meanwhile, Sofyan and Sundawa found that the application of Civic Education course as a general basic course in higher education has a significant influence on the increasing of students' nationalism insight and spirit at STKIP Garut (Sofyan and Sundawa, 2015: 185-99). Furthermore, Qodir specifically examined the Acehnese students' views, who studied in Yogyakarta, concerning Indonesian nationalism insight. The choice of Aceh as the subject of study is linked to the fact that the region is often identified with separatism. His research concluded that Indonesian nationalism for the Acehnese people was an idea imposed by the New Order. Conception of nationalism insight in Aceh did not well accommodate the local values existing in Acehnese society (Qodir, 2013: 52-7).

This current study is of interest because it enriches references of the implementation of Tridharma in higher education, especially Islamic higher education or Perguruan Tinggi Keagamaan Islam (PTKI). It specifically discusses the extent to which Indonesian nationalism insight is practiced at IAIN Pekalongan. Here, the writers want to reveal the implementation of Indonesian national insight in the aspect of teaching, research and community service. The study uses a descriptive-qualitative approach to present a systematic, factual and accurate explanation dealing with the facts, characteristics and relationships between events being investigated. Data of the study were sourced from Renstra or Rencana Strategis (the strategic plan), academic instructional guideline, research and community service programs in 2017 and 2018, period that marks the new chapter of the institution after its conversion from STAIN Pekalongan into IAIN Pekalongan. 


\section{B. Discussion}

\section{Defining Indonesian Nationalism Insight}

Conception of Indonesian nationalism insight refers to the words constructing the term, i.e. insight and Indonesian nationalism. Simply speaking, insight means a perspective. In a more operational sense, it is a perspective that stems from a philosophy of life containing aspiration and motivation to achieve the national goals and ideals. Such an insight is born from the overall one's personality in responding to his or her environment (Ristekdikti, 2016: 21216). Meanwhile, Indonesian nationalism refers to a sense of love to all the existing diversity and uniqueness found in Indonesia as a nation that has helped shape the country since its preindependence to the present time. It is understood as one's acknowledgment of the fact that the diversity of regions, ethnicities, cultures, religions and languages is united under Indonesia, also known as Bhinneka Tunggal Ika or Unity in the Diversity.

The above definition implies that Indonesian nationalism insight is basically intended to revive the noble personality of Indonesian people. It is an awareness to love Indonesia with all its strengths and weaknesses. This notion suggests that awareness must grow from below (society), rather than from above (the state) through formal rules. Indonesian nationalism insight does not focus on the regional origins, ethnicity, descent, social status, religion or beliefs, but on the noble values that have grown and developed in the archipelago passed down from generation to generation and that have served as a way of life for every Indonesian citizen.

In the global geopolitical view, for example, Indonesia has a strategic position because of its location between two continents and two oceans. This geographical location brings opportunities as well as threats to the country's sovereignty. On the one hand, the potential of natural resources in Indonesia is a big capital for the government to realize its national goals and ideals. Biodiversity both on land and at sea has contributed greatly to the welfare of society. On the other hand, Indonesia is also a meeting point where interests of various countries may exist (Ditjendikti, 2012: 11424). In this context, Indonesia's location brings vulnerability because many countries will undoubtedly intervene in the government policies for the sake of their national interests.

Besides, the development of science and technology in the globalization era has significant impact on the increasingly complex threats to the Indonesian nation. This notion makes sense since the threats are not always visible in physical forms but also latent, like the emergence of cultural and ideological hegemony as a result of the globalized world (Bourdieu and Wacquant, 1999: 41-58) through cyberspace networks. The caliphate-based propaganda 
Ade Dedi Rohayana dan Muhammad Jauhari Sofi

through the use of social media actively driven by a group of people demanding the implementation of Islamic sharia is an obvious example (Yunarto, 2015: 55-96).

The rapid pace of globalization also leads to the problem of national identity due to the dominance of certain cultures (Skelton and Allen, 1999: 23). People are now easy to follow new cultural patterns not having been tested for their compatibility with the national identity, while the nation's noble values having existed for a long time are perceived as an old product that does not fit the needs of the times. This identity crisis is further manifested in individualism and egotism. Such attitudes are contrary to the values of Pancasila that emphasizes the spirit of togetherness, cooperation, mutual respect and equality.

\section{Higher Education's Tridharma}

Etymologically, the term Tridharma comes from Sanskrit origin. Tri literally means three, and dharma means obligation. In practice, Tridharma or Three Pillars is broadly understood as the three obligations of Higher Education to carry out teaching, research and community service as stipulated in Law No. 12 of 2012, Article 1 Paragraph 9. The mandate to implement Tridharma applies to all Higher Education in Indonesia, both public and private, both general and Islamic-based.

First, teaching is defined as a conscious and planned effort to create a learning atmosphere and learning process. In this sense, students are actively trained to develop their potential to have religious spiritual strength, self-control, personality, intelligence, noble character, and skills needed by themselves, society, nation and state. Second, research is an activity carried out according to scientific principles and methods to obtain information, data and explanation used to understand and/ or to test a branch of science and technology. Third, community service is a program, conducted by civitas academica, which utilizes science and technology to better the welfare of community and to educate people of the nation (UU RI No 12 Tahun 2012).

Lecturers as part of civitas academica in higher education have the main task of transforming, developing and disseminating science, technology and art through teaching, research and community service. They are also required to prepare textbooks, usually

published by universities, or scientific publications as a source of learning (UU RI No 12 Tahun 2012). In general, there are two tasks of a lecturer, i.e. the main task and the supporting task. The main task deals with the implementation of the Three Pillars of Higher Education including teaching, research and community service. Meanwhile, the supporting tasks are 
concerned with additional duties performed both inside and outside the institution where the lecturer is assigned (UU RI No 12 Tahun 2012).

In Higher Education, students are positioned as adult learners whose awareness is believed to be able to develop their own potential to become intellectuals, scientists, practitioners or professionals. While prioritizing reasoning, noble character and responsibility, they have freedom in accordance with academic culture. Students are entitled to get educational services according to their talents, interests, potential and abilities. They are also given the right to be able to complete the education program in accordance with their respective learning speeds and not exceeding the time limit stipulated by the Higher Education (UU RI No 12 Tahun 2012).

\section{Indonesian Nationalism Insight at IAIN Pekalongan}

Historically, the State Islamic Institute or Institut Agama Islam Negeri (IAIN) of Pekalongan is an Islamic Higher Education originated from the Sharia Faculty at Bumiayu established in 1968. The faculty was then nationalized in 1970 and became one of the branch faculties of IAIN Walisongo Semarang. Along with the development of the government policies within the Ministry of Religious Affairs (MoRA), at the MoRA's HAB speech on January 3, 1997, the Minister announced the steps in developing the Islamic higher institutions. The policies were then outlined in the Presidential Decree No.11 of 1997, March 21, 1997 concerning the establishment of 33 State Islamic Colleges or Sekolah Tinggi Agama Isam Negeri (STAIN) throughout Indonesia, including STAIN Pekalongan (Tim IAIN Pekalongan, 2017b).

Later on August 1, 2016, STAIN Pekalongan was officially converted to the IAIN Pekalongan through Presidential Regulation of the Republic of Indonesia Number 73 of 2016. Thus, the existence and the development of IAIN Pekalongan were motivated by a spirit to develop to meet the needs of the community, especially the ex-Residency of Pekalongan and its surroundings. In the future, IAIN Pekalongan is projected to be able to convert to UIN Pekalongan to broaden the scope of Islamic studies (Team of IAIN Pekalongan, 2017b).

Indonesian nationalism insight is one of the core values in the developmental programs at IAIN Pekalongan. This value is evidenced by the existence of the term in IAIN Pekalongan's Vision, namely to become a leading and competitive Islamic Higher Education or Perguruan Tinggi Keagamaan Islam (PTKI) in developing science and technology based on Indonesian nationalism insight at the national level in 2036. This vision is demonstrated not only by performing good governance, but also by integrating Islamic sciences with general 
Ade Dedi Rohayana dan Muhammad Jauhari Sofi

sciences and promoting Indonesian nationalism insight in the Three Pillars of Higher Education (Team of IAIN Pekalongan, 2017b).

\section{Aspect of Teaching}

IAIN Pekalongan has committed to carry out instructional activity that is in line with the vision and mission of the institution, including the implementation of Indonesian nationalism insight. Some educational policies related to the curriculum and instructional activities are studied in depth to suit the vision and mission of the institution. The policies are directed to answer the needs of students and stakeholders, as well as reflect the developmental programs of scientific knowledge based on Indonesian perspective.

The implementation of Indonesian nationalism insight in instructional activity can be viewed in terms of lecturers, students, learning process and extracurricular activities. Concerning the lecturers, IAIN Pekalongan has conducted a rigorous selection of recruitment to assess both their academic competence and their Indonesian nationalism insight. This step is crucial because lecturer is the key factor to the success of instructional activity that is in line with Indonesian values. They are the people who directly interact and communicate with students in daily routines. It is believed that the coming of lecturers who have a strong commitment to Indonesia will help minimize the influences of ideology contrary to the nation's character.

A review of Indonesian insight was also applied to new students after they officially became part of the academic community at IAIN Pekalongan. Each student was interviewed and asked to respond to several important issues that have the potential to cause horizontal conflict and controversy, such as the enactment of Islamic law, violence against adherents of other faiths, rejection of the flag ceremony and so on. This interview was used as an early detection as well as a mapping of students' level of insight and commitment to the Unitary State of the Republic of Indonesia/Negara Kesatuan Republik Indonesia (NKRI). Students indicated to have an understanding that was not in accordance with the Indonesian nationalism insight were then given special guidance and assistance by their supervisor so that they might gain a correct understanding of the insight.

The implementation of Indonesian nationalism insight can also be seen from the instructional planning prepared by the lecturer. In this case, IAIN Pekalongan requires lecturers to prepare a semester syllabus or Rencana Pembelajaran Semester (RPS) before a particular course begins. This syllabus is then submitted to the department office to obtain authorization (or revision). Plans that are not in line with Indonesian nationalism insight will 
not be approved because are contrary to the vision and mission of the institution. In addition, IAIN Pekalongan conducts a learning monitoring system by students. Students are involved to participate in assessing the performance of lecturers in classrooms. Any material not reflecting the nation's identity will be reported to the in-charge board.

More specifically, IAIN Pekalongan also requires students to take courses of Pancasila and Civic Education and Indonesian Language. The first course (three credits) discusses Pancasila as the state ideology, the 1945 Constitution, the Unitary State of the Republic of Indonesia and Bhinneka Tunggal Ika (Unity in Diversity). This course is very important to equip students and graduates to have personalities with the character of national identity. In addition, it is also intended to hearten younger generation to contribute to and realize the national goals through education and learning processes (Team of IAIN Pekalongan, 2017a: 20-21). Meanwhile, the second course (two credits) is intended to encourage students to maintain the national language and have pride in it because the language is the national identity. Awareness in maintaining and feeling proud of the national language is expected to spur students to use Indonesian correctly (Team of Pekalongan, 2017a: 20-21).

Next, the application of curriculum at IAIN Pekalongan has been adjusted to the National Higher Education Standards/Standar Nasional Pendidikan Tinggi (SNPT) and refers to the Indonesian National Qualification Framework or Kerangka Kualifikasi Nasional Indonesia (KKNI). In this KKNI-based curriculum, implementation of education in all departments or study programs must be in harmony with the character and personality of Indonesian people, the state ideology and the Indonesian culture. The curriculum emphasizes students to always fear God, maintain morals and ethics, love their homeland and nation, have social sensitivity, respect diversity and uphold law enforcement (Dirjenpendis Kemenag, 2018).

Furthermore, Indonesian nationalism insight on the aspect of teaching was also implemented in student extracurricular activities under the supervision of an academic supervisor. These activities can broaden horizon and hone skills not obtained from the classroom. By participating in activities outside of lectures, students will be trained to interact with individuals and communities from diverse backgrounds. Later, the habit of sharing experiences and perspectives within organizations will be very useful in the broader context of interaction in the diverse Indonesian society. 
Ade Dedi Rohayana dan Muhammad Jauhari Sofi

\section{Aspect of research}

Research activities at IAIN Pekalongan are managed by LP2M (the Center for Research and Community Service). Description of the research themes held at IAIN Pekalongan in 2017 and 2018 is as follows:

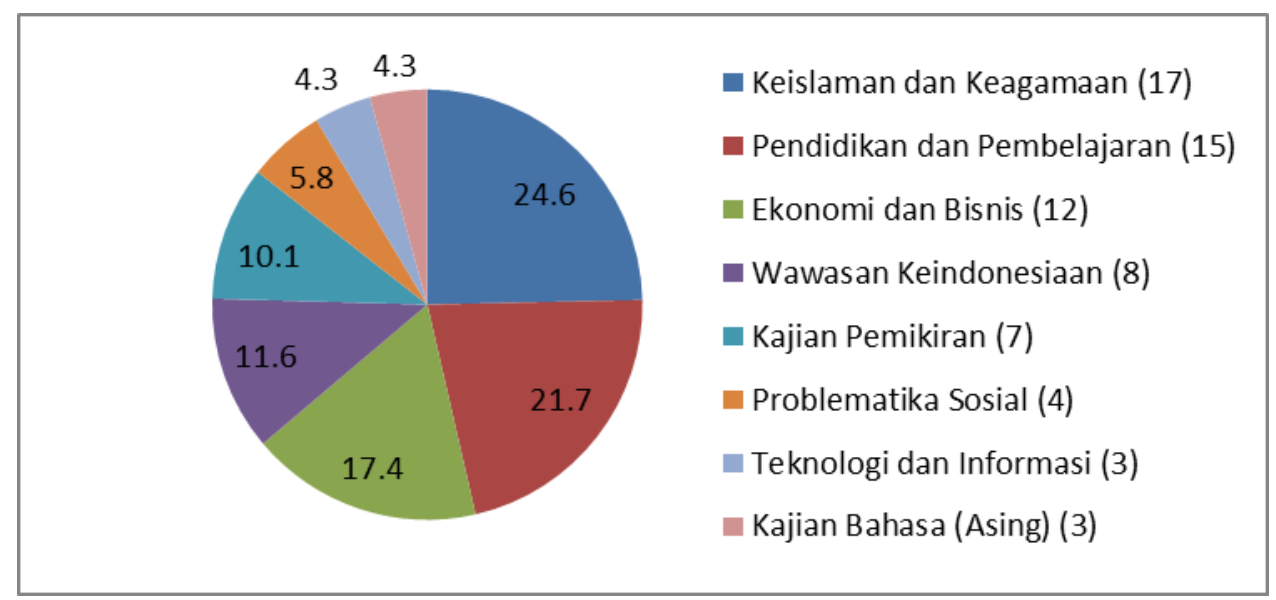

Figure 1: Percentage of Research in 2017 Based on Study Themes

The chart shows that in 2017 there were about eight research themes, i.e. Islamic studies, education, business and economics, Indonesian studies, thoughts, social problems, information-technology and language. In that year, IAIN Pekalongan had conducted 69 researches comprising 19 beginner clusters, 28 intermediate clusters, 19 advanced clusters and 3 intellectual property clusters. Of those 69 researches, 17 researches $(24.6 \%)$ discussed Islam or religion, 15 researches $(21.7 \%)$ discussed education and learning, 12 researches $(17.4 \%)$ discussed economics and business, 8 researches $(11.6 \%)$ discussed Indonesian insight, 7 researches $(10.1 \%)$ discussed thought studies, 4 researches $(5.8 \%)$ discussed social problems, 3 researches $(4.3 \%)$ discussed technology and information and 3 researches $(4.3 \%)$ discussed language studies (IAIN Pekalongan, 2017c).

The research themes in 2017 at IAIN Pekalongan still have a lot to do with study program issues within the institution's internal environment. Indonesian national insight, as a general issue not directly related to the study program, has not received significant attention. Evidently, themes concerned with Islam, learning and economics still dominates, while those with Indonesian nationalism insight ranks only fourth $(11.6 \%)$ out of the eight research themes. Moreover, findings related to the insight have also not been used as material for strategic and practical policy considerations, so they have not contributed maximally to the maintenance of Indonesian values in the institution and the local community. 


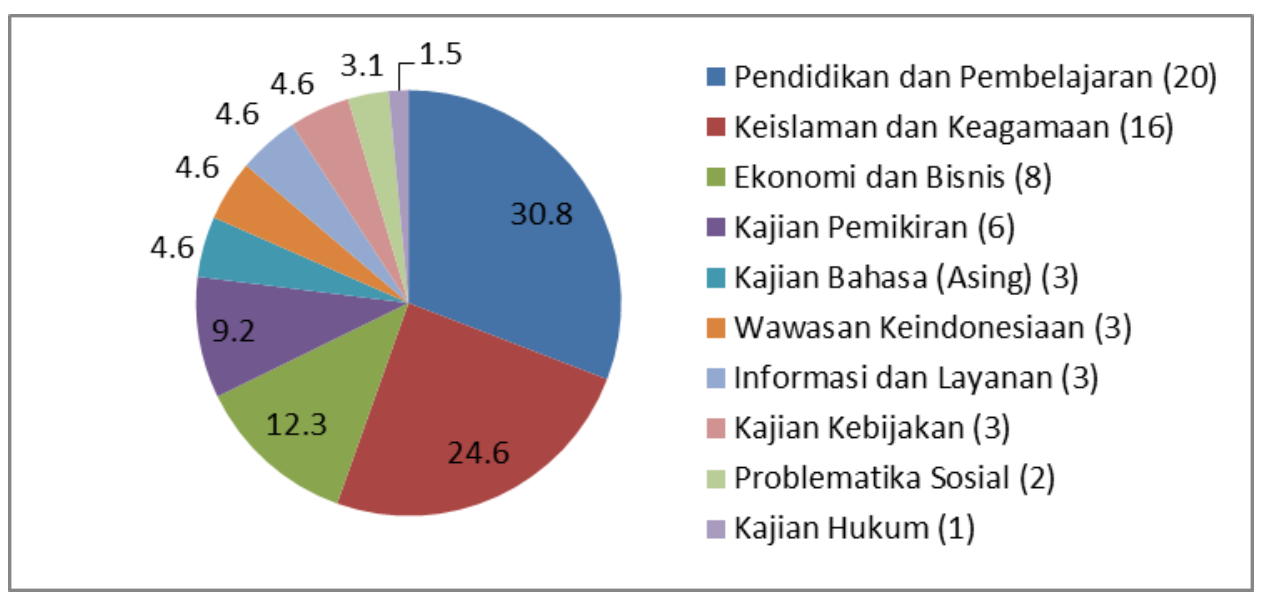

Figure 2: Percentage of Research in 2018 Based on Study Themes

Meanwhile, there were ten research themes in 2018, including education, Islamic studies, business and economics, thoughts, Indonesian studies, language, information and services, social problems, policy and law. In that year, IAIN Pekalongan conducted 65 researches comprising 32 capacity building clusters, 23 study program-based clusters, 9 interdisciplinary study clusters and 1 policy cluster. Of the 65 studies, 20 researches $(30.8 \%)$ discussed education and learning, 16 researches $(24.6 \%)$ discussed Islam or religion, 8 researches $(12.3 \%)$ discussed economics and business, 6 researches $(9.2 \%)$ discussed thought studies, 3 researches $(4.6 \%)$ discussed language, 3 researches $(4.6, \%)$ discussed Indonesian insight, 3 researches (4.6\%) discussed information and services, 3 researches (4.6\%) discussed policies, 2 researches $(3.1 \%)$ discussed social problems, and 1 research $(1.5 \%)$ discussed law (IAIN Pekalongan, 2018c).

As in 2017, the research themes in 2018 at IAIN Pekalongan were still much related to the study program within the institution's internal environment. However, the research themes have been slightly developed with the emergence of two new themes, i.e. policy and law. Islamic themes, learning and economics still dominate despite the shift in numbers. Meanwhile, Indonesian nationalism insight actually declined (3 researches) and only ranked sixth $(4.6 \%)$ out of the ten research themes. Findings related to the insight have also not been used as material for strategic and practical policy considerations. The three researches related to Indonesian nationalism insight are nationalism education in early childhood, multiculturalism values in the local ulema's thoughts and Indonesia-based Islamic jurisprudence (fiqh). 
Ade Dedi Rohayana dan Muhammad Jauhari Sofi

\section{Aspect of community service}

Programs in the field of community service by IAIN Pekalongan are carried out as a manifestation of the practice of Islamic science and knowledge, of the relationship between programs at IAIN Pekalongan and needs of community and of the implementation of integrated area development through the Village Assistantship or Village Partnership programs. These community service programs are managed by the Center for Research and Community Service (LP2M) and include two main programs, i.e. the Field Work Lecture or Kuliah Kerja Nyata (KKN) by students and the Village Assistantship by lecturers. Themes of the community service in 2017 and 2018 are as follows.

The community service programs in 2017 through KKN Batch 42 Phase 1 include 21 locations (villages) with theme of study program-based community services. Likewise, the community service programs in 2017 through KKN Batch 42 Phase 2 include 21 locations (villages) with theme of study program-based community services (IAIN Pekalongan, 2017b). Next, the community service programs in 2017 through KKN Batch 43 include 40 locations (villages) with the following themes: mosque-based community mentoring, community empowerment through entrepreneurship, improving the quality of family life, children-friendly villages, environment-friendly villages, literacy village and household economic development (IAIN Pekalongan, 2017d). The community service programs in 2018 through KKN Batch 44 and Batch 45 specifically take theme of Community Empowerment through the Social Entrepreneurship Development Program for Local Community (IAIN Pekalongan, 2018b, 2018d).

From the above data, the Community Service Programs developed by LP2M through $\mathrm{KKN}$ in 2017 and 2018 do not specifically address the Indonesian nationalism insight as referred to in the theoretical framework, i.e. themes that are specifically intended to build nationalism awareness in relation to the multilayer and complex diversity in Indonesia. The themes in 2017 and 2018 are generally related to community empowerment, community capacity building, direct service to the community and application of science-knowledge with reference to the existing study programs at IAIN Pekalongan.

Meanwhile, the community services through Village Assistantship by lecturers in 2017 include 21 programs, namely children-friendly village, ihyaus sunnah-based village development 1 , society and religion-based empowerment, ihyaus sunnah-based village development 2, rural economy-strengthening program, prostitution chain-breaking program, happy young family, mosque functions-based revitalization, eco-friendly village, sufi-healing, science village, citizen journalism, international batik village, mosque-based empowerment, 
mosque youth empowerment, literacy village, sakinah family-based revitalization, (foreign) language and culture village, madrasa-based empowerment, fish farming, waste management, village financial management and child-protecting literacy (IAIN Pekalongan, 2017a).

Next, the community services through Village Assistantship by lecturers in 2018 include 23 empowerment programs and 4 advocacy programs. The 23 empowerment programs are (women) community empowerment of productive age, ihyaus sunnah-based village development, ecotourism-strengthening management, Islamic parenting education, flood-affected family resilience, zakat-infaq-alms management, legal literacy village, bullyingconcerned education for elementary school students, information and communication media literacy village, imam-mentoring program, prostitution-concerned Islamic counseling, science literacy zone, mosque functions-based actualization, drug-free spiritual guidance, minority Muslim empowerment towards scholarship community, gadget-based technology literacy, creative economy-based empowerment, assistance in making local community-based BUMDes, coffee yields management, tea production innovation, village information system management and waste management. Further, the 4 advocacy programs cover public advocacy in the economics, in education 1, in legal matters and in education 2 (IAIN Pekalongan, 2018a).

The entire community service programs from the lecturers in 2017 and 2018 do not specifically address the Indonesian nationalism insight as referred to in the theoretical framework. Instead, the programs are intended as an effort to empower the community in specific social and religious areas. In addition, there has not been an evaluation concerning how big the impact of those programs on social change is. Follow-up towards the said programs has not also been carried out.

\section{Analysis of Challenges}

The first pillar of Tridharma is concerned with teaching and education. Policies concerning instructional activity at IAIN Pekalongan are always directed to meet the needs of students and stakeholders, that is, to develop science and knowledge that are based on Indonesian nationalism insight. Several policies related to instructional activity at IAIN Pekalongan have been implemented. First, each lecturer is required to teach a minimum of 12 credits (SKS) per semester. Second, each lecturer is required to prepare teaching plan, e.g. semester syllabus. Third, each lecturer is required to fill in Sikadu (integrated academic system) consisting of teaching journals, students attendance, mentoring and assessment to control instructional activities. Fourth, monitoring and evaluation towards lecturer activities 
Ade Dedi Rohayana dan Muhammad Jauhari Sofi

are based on the Lecturer Performance Index (IKD), Student Satisfaction Index (IKM), observation by the department through attendance and control card brought by students. Finally, fifth, all departments are required to prepare, design and implement the KKNI curriculum.

However, those policies have not been running optimally due to several factors, so that developmental programs of science and knowledge based on Indonesian nationalism insight at IAIN Pekalongan have also been hampered. First, many lecturers get more semester credits (SKS) in one semester due to the limited number of lecturers available to teach. Second, there is no standard syllabus agreed upon yet, so that each lecturer may make different interpretation of it. Third, reward and punishment regarding the results of lecturers' performance evaluation have not been clearly expressed. Fourth, lecturers who specifically have the qualifications to teach Pancasila and Civic Education as well as Indonesian Language are still limited in number. Finally, fifth, the concept of KKNI is not yet fully understood by each lecturer, so that the formulation and preparation of the KKNI-based curriculum have not been satisfactorily accomplished.

The second pillar of Tridharma is concerned with research. The majority of research at IAIN Pekalongan was conducted by lecturers (90\%), both individually and collectively. So far, the researches are still focused on issues in the institution's internal environment, while broader themes, such as Indonesian nationalism insight, have not been given significant attention yet. In addition, most of them still employ a mono-disciplinary approach, so that they have less appeal and impact on the real social change. Later, based on the benefits, findings of the researches both by lecturers and by students at IAIN Pekalongan can be explained as follows. First, the findings of the researches have not yet made a maximum contribution to the improvement of institutional management, learning, academic atmosphere and human resources. Second, the findings of the researches have not been used as a material for strategic and practical policy considerations both for the internal party (civitas academica) and for the external party (the community). Third, the findings of the researches have not been published in reputable national or international journals as a medium to disseminate science and knowledge.

The third pillar of Tridharma is concerned with community service. Some policies in the aspect of community service are around: (1) practicing the Islamic science and knowledge, (2) strengthening the relationship between the programs at IAIN Pekalongan and the needs of community to help them carry out empowerment and (3) implementing the integrated area development through the Village Assistantship programs. As the researchers observed, the 
community service programs do not explicitly accommodate the issue of Indonesian nationalism insight, nor have they focused on the real problems faced by the community. Further, based on the benefits, the results of the community service programs conducted by both lecturers and students of IAIN Pekalongan can be explained as follows. First, synergy between instructional activities, researches and community service programs has not been well established. Second, the results of the programs have not been used as a material for strategic and practical policy considerations both for the internal party (civitas academica) and for the external party (the community). Third, the programs in community service have not involved the third party yet. Fourth, the results of the programs have not been published in reputable national or international journals for broader benefits.

\section{Conclusion}

Indonesian nationalism insight is a theme urgent to be socialized to the wider community, especially younger generation. This is so because the theme directly touches on the most fundamental aspect in the life of Indonesian society; it is closely related to national identity. At the higher education level, Indonesian nationalism insight is intended to foster love for the nation, both in civitas academica and in local community. This study concerned with implementation of Indonesian nationalism insight in the Three Pillars of Higher Education or Tridharma Perguruan Tinggi at IAIN Pekalongan concluded that: (1) the implementation of Indonesian nationalism insight in the aspect of teaching was effective only at the policy level, such as the recruitment of teaching staff or lecturers, students coaching, instructional curriculum and extracurricular supervision. The policy has not been able to be realized maximally due to several factors, such as the limited number of lecturers who have qualifications to teach Pancasila and Civic Education. (2) The implementation of Indonesian nationalism insight in the aspect of research is still limited. From 134 researches in 2017 and 2018 , there were only 11 studies (8.2\%) that discussed Indonesian nationalism insight, such as nationalism education in early childhood and multiculturalism values in the local ulema's thoughts. Important to notice, findings of these researches have not been followed up with strategic or practical policies. (3) The implementation of Indonesian nationalism insights in the aspect of community service as referred to in the theoretical framework, namely to build nationalism awareness in relation to the multilayer and complex diversity in Indonesia, has not been explicitly accommodated. The existing programs of community service mainly revolve around community empowerment in specific social and religious areas. 
Ade Dedi Rohayana dan Muhammad Jauhari Sofi

\section{REFERENCES}

Alvara Research Center. 2018. "Survei Alvara: Sebagian Milenial Setuju Khilafah.” CNN Indonesia. https://www.cnnindonesia.com/nasional/20180307191320-20281228/survei-alvara-sebagian-milenial-setuju-khilafah.

Apriani, Eka. 2017. "The Misuse of ICT by Students: The Effects of Phornography and the Teacher Solutions." Tadrib: Jurnal Pendidikan Agama Islam 1(2): 185-203. http://jurnal.radenfatah.ac.id/index.php/Tadrib/article/view/1046.

Bourdieu, Pierre, and Loic Wacquant. 1999. "On the Cunning of Imperialist Reason.” Theory, Culture \& Society 16 (1): 41-58. https://doi.org/10.1177/026327699016001003.

Dirjenpendis Kemenag. 2018. SKL Dan CPL Prodi Jenjang Sarjana Pada PTKI Dan Fakultas Agama Islam Pada Perguruan Tinggi. Jakarta.

Ditjendikti. 2012. Modul Kuliah Kewarganegaraan. Jakarta: Ditjen Dikti.

Fibrianto, Alan Sigit, and Syamsul Bakhri. 2018. "Pelaksanaan Aktivitas Ekstrakurikuler Paskibra Dalam Pembentukkan Karakter, Moral Dan Sikap Nasionalisme Siswa SMA Negeri 3 Surakarta." Jurnal Moral Kemasyarakatan 2(2): 75-93.

Giddens, Anthony. 1990. The Consequences of Modernity. Stanford: Stanford University Press.

Halim, Devina. 2018. "BIN: 7 Perguruan Tinggi Negeri Terpapar Paham Radikal." Kompas. https://nasional.kompas.com/read/2018/11/20/23070271/bin-7-perguruan-tingginegeri-terpapar-paham-radikal.

Haryati, Mila Septian. 2018. "Menumbuhkan Nasionalisme Pada Siswa Melalui Kegiatan Ekstrakurikuler Pasukan Pengibar Bendera: Studi Kasus Di MAN 2 Model Mataram.” Jurnal Pendidikan Sosial Keberagaman 5(2): 163-79.

IAIN Pekalongan, Rektor. 2017a. SK Rektor IAIN Pekalongan Nomor: 120 Tahun 2017 Tentang Bantuan Program Pemberdayaan Kepada Masyarakat Berbasis Program Studi.

-_- 2017b. SK Rektor IAIN Pekalongan Nomor: 156 Tahun 2017 Tentang Bantuan Dana Pelaksanaan Pengabdian Kepada Masyarakat Melalui KKN Angkatan 42.

-_- 2017c. SK Rektor IAIN Pekalongan Nomor: 179 Tahun 2017 Tentang Penetapan Penerima Dana Bantuan Penelitian Dosen Tahun 2017.

_-_ . 2017d. SK Rektor IAIN Pekalongan Nomor: 396 Tahun 2017 Tentang Bantuan Dana Pelaksanaan Pengabdian Kepada Masyarakat Melalui KKN Angkatan 43.

- - - 2018a. SK IAIN Pekalongan Nomor: 173 Tahun 2018 Tentang Bantuan Program Pemberdayaan Kepada Masyarakat Berbasis Program Studi.

_——. 2018b. SK Rektor IAIN Pekalongan Nomor: 161 Tahun 2018 Tentang Bantuan 
Dana Pelaksanaan Pengabdian Kepada Masyarakat Melalui KKN Angkatan 44.

_-_. 2018c. SK Rektor IAIN Pekalongan Nomor: 185 Tahun 2018 Tentang Penetapan Penerima Dana Bantuan Penelitian Dosen Tahun 2018.

_-_. 2018d. SK Rektor IAIN Pekalongan Nomor: 272 Tahun 2018 Tentang Bantuan Dana Pelaksanaan Pengabdian Kepada Masyarakat Melalui KKN Angkatan 45.

Kayane, Yuka. 2020. "Understanding Sunni-Shi'a Sectarianism in Contemporary Indonesia: A Different Voice from Nahdlatul Ulama under Pluralist Leadership.” Indonesia and the Malay World 48(140): 78-96. https://doi.org/10.1080/13639811.2020.1675277.

Marwanti, Endah. 2016. "Membangun Semangat Nasionalisme Di Sekolah Melalui Kearifan Lokal.” Trihayu 3(1): 55-63.

Masamah, Ulfa, and Mualimul Huda. 2016. "Multicultural Education and the Nationalistic Reality (Photograph the Role of Teachers in Building a Multicultural Awareness in Indonesia).” QIJIS (Qudus International Journal of Islamic Studies) 4(1): 68-81. http://journal.stainkudus.ac.id/index.php/QIJIS/article/view/1578.

Maulana, Dirga. 2017. “The Exclusivism of Religion Teachers: Intolerance and Radicalism in Indonesian Public Schools." Studia Islamika 24(2): 395-401.

Mietzner, Marcus, and Burhanuddin Muhtadi. 2018. "Explaining the 2016 Islamist Mobilisation in Indonesia: Religious Intolerance, Militant Groups and the Politics of Accommodation." Asian Studies Review 42(3): 479-97. https://doi.org/10.1080/10357823.2018.1473335.

Mutohar, Agus. 2018. "Countering the Rise of Radicalism in Private Islamic Schools in Indonesia." The Jakarta Post. https://www.thejakartapost.com/academia/2018/05/17/countering-the-rise-ofradicalism-in-private-islamic-schools-in-indonesia.html.

News Desk. 2019. "Government to Revise Religion Studies School Books as Some Found to Hint at Radicalism, VP Says.” Asia Pacific Solidarity Network. https://www.asia-pacificsolidarity.net/news/2019-11-28/government-revise-religion-studies-school-bookssome-found-hint-radicalism-vp-says.html.

Qodir, Zuly. 2013. “Studi Tentang Pandangan Keindonesiaan.” Prosiding Konferensi Nasional Ke- 3: 42-57. http://repository.umy.ac.id/handle/123456789/32830.

Ristekdikti. 2016. Pendidika Kewarganegaraan Untuk Perguruan Tinggi. 1st Editio. Jakarta: Kemenristekdikti.

Santoso, Listiyono, and Moses Glorino Rumambo. 2017. "Pendidikan Karakter Sebagai Strategi Penguatan Wawasan Kebangsaan Mahasiswa.” Seminar Nasional Keindonesiaan 1(2017): 1-13. https://ojs.unm.ac.id/PSN-HSIS/article/view/2760/1501. 
Ade Dedi Rohayana dan Muhammad Jauhari Sofi

Setiawan, Deny. 2016. "Pengembangan Kurikulum Pendidikan Berbasis KKNI Dan Berwawasan Kebangsaan Sebagai Program Dukungan Pembangunan Berkelanjutan Di Bidang Pendidikan." Seminar Nasional "Pendidikan Ilmu-Ilmu Sosial Membentuk Karakter Bangsa Dalam Rangka Daya Saing Global” Kerjasama: Fakultas Ilmu Sosial Universitas Negeri Makassar dan Himpunan Sarjana Pendidikan Ilmu-ilmu Sosial Indonesia: $349-54$.

———. 2017. "Kontribusi Tingkat Pemahaman Konsepsi Wawasan Nusantara Terhadap Sikap Nasionalisme Dan Karakter Kebangsaan.” Jurnal Pendidikan Ilmu-Ilmu Sosial (JPIIS) 9(1): 24-33.

Skelton, Tracey, and Tim Allen. 1999. Culture and Global Change. London: Routledge.

Sofyan, Fitri Silvia, and Dadang Sundawa. 2015. "Hubungan Mata Kuliah Pendidikan Kewarganegaraan Dengan Peningkatan Wawasan Kebangsaan Dan Semangat Nasionalisme Mahasiswa." Jurnal Pendidikan Ilmu Sosial 24(2): 185-99.

Surono, Kabul Aris. 2017. "Penanaman Karakter Dan Rasa Nasionalisme Pada Kegiatan Ektrakurikuler Pramuka Di SMP N 4 Singorojo Kabupaten Kendal.” Indonesian Journal of Conversation 6(1): 23-30. https://journal.unnes.ac.id/nju/index.php/ijc/article/view/12527.

Syahrir, Sulthan. 2018. "Islamic Education With Nationalism Insight Viewed from Islamic Perspective." Jurnal Ilmiah Peuradeun 6(1): 121-40. http://journal.scadindependent.org/index.php/jipeuradeun/article/view/192.

Taubah, Mufatihatut, and Uswatun Chasanah. 2018. "Peranan Gerakan Pramuka Dalam Menanamkan Sikap Nasionalisme Di Madrasah Ibtidaiyah: Studi Kasus Di MIN Kudus Tahun Pelajaran 2017/2018." Elementary6(2):337-54.

Team of IAIN Pekalongan. 2017a. Panduan Pengembangan Kurikulum Berbasis KKNI: Sarjana Dan Magister. Pekalongan: IAIN Pekalongan.

_- - 2017b. Rencana Strategis (Renstra) IAIN Pekalongan 2017-2021. Pekalongan: IAIN Pekalongan.

UU RI No 12 Tahun 2012. 2012. Undang-Undang Republik Indonesia Nomor 12 Tahun 2012 Tentang Pendidikan Tinggi.

Yunarto, Sri. 2015. "Terorisme Di Indonesia: Konsep, Tipologi Dan Strategi Penanggulangannya." In Deradikalisasi: Kontra Radikalisme Dan Deideologisasi, Jakarta: Badan Litbang dan Diklat Kemenag RI, 55-96.

Zulkarnain, Fisher, and Tata Septayuda Purnama. 2016. "The ISIS Movement and the Threat of Religious Radicalism in Indonesia." Mimbar 32(1): 31-39. https://ejournal.unisba.ac.id/index.php/mimbar/article/view/1590/pdf. 